\title{
Salt balance in substrate cultivated with 'Sunki' mandarin x 'Swingle' citrumelo hybrids
}

\author{
Juliana F. Almeida ${ }^{1}$, Giuliana N. B. Sales ${ }^{1}$, Marcos E. B. Brito ${ }^{2}$, \\ Pedro D. Fernandes ${ }^{3}$, Walter S. Soares Filho ${ }^{4} \&$ Isidro P. Almeida Neto ${ }^{1}$
}

${ }^{1}$ Universidade Federal de Campina Grande/Centro de Ciências e Tecnologia Agroalimentar/Unidade Acadêmica de Ciências Agrárias. Pombal, PB. E-mail: julianaformiga962@gmail.com (Corresponding author) - ORCID: 0000-0001-5844-4569; giulianasales@outlook.com - ORCID: 0000-0002-4909-6774; isidroneto2@gmail.com - ORCID: 0000-0003-1727-5767

${ }^{2}$ Universidade Federal de Sergipe/Centro de Ciências Agrárias do Sertão/Núcleo de Graduação em Educação em Ciências Agrárias e da Terra. Nossa Senhora da Glória, SE. E-mail: marcoseric@ufs.br - ORCID: 0000-0001-9087-3662

${ }^{3}$ Universidade Federal de Campina Grande/Centro de Tecnologia e Recursos Naturais. Campina Grande, PB. E-mail: pdantas@pq.cnpq.br - ORCID: 0000-0001-5070-1030

${ }^{4}$ Embrapa Mandioca e Fruticultura. Cruz das Almas, BA. E-mail: walter.soares@embrapa.br - ORCID: 0000-0001-5410-3740

\section{Key words: \\ Citrus spp. \\ rootstocks \\ tolerance \\ salinity}

\begin{abstract}
A B S T R A C T
During initial plant development stage, an experiment was conducted to evaluate the balance of salts in the substrate used for the production of 10 hybrids from the cross between 'Sunki' mandarin (TSKC) and 'Swingle' citrumelo (CTSW), all with potential to be used as rootstock. 'Rangpur Santa Cruz' lime, 'Sunki Tropical' mandarin and the hybrid LVK ('Volkamer' lemon) x LCR ('Rangpur' lime) - 038 were included as controls, totaling 13 genotypes. Substrate samples were collected in the experiment conducted in a greenhouse at the Federal University of Campina Grande, Campus of Pombal, from December 2015 to June 2016. Two levels of irrigation water salinity were tested, using a 2 × 13 factorial scheme, with 4 replicates. The substrate was a mixture of vermiculite, pine bark and humus (1:1:1). For the salinity level of $3 \mathrm{dS} \mathrm{m}^{-1}$, the substrate is less salinized when cultivated with the hybrids TSKC x CTSW - 044, TSKC x CTSW - 045, TSKC x CTSW - 048, TSKC $\mathrm{x}$ CTSW - 049 and 'Rangpur Santa Cruz' lime. On the other hand, highest salt concentration was obtained in the substrate cultivated with TSKC x CTSW - 042, TSKC x CTSW - 047, TSKC x CTSW - 048, TSKC x CTSW - 053, TSKC x CTSW - 055 and TSKC x CTSW - 057.
\end{abstract}

\section{Palavras-chave:}

Citrus spp.

porta-enxerto

tolerância

salinidade

\section{Balanço de sais em substrato de cultivo de híbridos de tangerineira 'Sunki' com citrumelo 'Swingle'}

\section{R E S U M O}

Em fase inicial de desenvolvimento da planta, objetivou-se avaliar o balanço de sais no substrato de cultivo de 10 híbridos do cruzamento tangerineira 'Sunki' comum (TSKC) $\mathrm{x}$ citrumelo 'Swingle' (CTSW), todos com potencial de uso como porta-enxertos. Como testemunhas incluiu-se o limoeiro 'Cravo Santa Cruz', a tangerineira 'Sunki Tropical' e o híbrido LVK (limoeiro 'Volkameriano') x LCR (limoeiro 'Cravo') - 038, somando um total de 13 genótipos avaliados. Foram coletadas amostras do substrato em experimento desenvolvido em ambiente protegido da Universidade Federal de Campina Grande, Pombal, $\mathrm{PB}$, de dezembro de 2015 a junho de 2016. Foram testados dois níveis de salinidade da água de irrigação $\left(0,3\right.$ e $\left.3 \mathrm{dS} \mathrm{m}^{-1}\right)$, em esquema fatorial $2 \times 13$, com 4 repetições, usando-se, como substrato, a casca de pinus, o húmus e a vermiculita na proporção 1:1:1. Considerando água de irrigação com nível de salinidade $3 \mathrm{dS} \mathrm{m}^{-1}$, o substrato mostra-se menos salinizado em relação aos híbridos TSKC x CTSW - 044, TSKC x CTSW - 045, TSKC x CTSW - 048 e TSKC x CTSW - 049, assim como para o limoeiro 'Cravo Santa Cruz'. Por outro lado, a maior concentração de sais foi obtida no substrato em que são cultivados TSKC x CTSW - 042, TSKC x CTSW - 047, TSKC x CTSW - 041, TSKC x CTSW - 053, TSKC x CTSW 055 e TSKC x CTSW - 057. 


\section{INTRODUCTION}

Salinity of soil and water is among the main problems in agriculture leading to reduction in crop yield (Gheyi et al., 2016). Despite being a global problem, salinity is more evident in arid and semi-arid regions, such as Northeast Brazil, for being characterized by low and irregular rainfall levels (Medeiros et al., 2003).

In addition, the predominance of waters with high levels of electrical conductivity in these regions should also be considered, reflecting in increased risk of salinization, if adequate management practices of plant, soil and water are not adopted (Araújo Neto et al., 2014; Dalastra et al., 2014).

The effects of salinity on agricultural production encompass osmotic effects, reducing water absorption by plants (Willadino \& Câmara, 2010), and ionic effects, which can cause phytotoxicity and nutritional imbalance. These effects culminate in reduction of growth and potential of plants considered as sensitive (Taiz et al., 2015), such as citrus, which have mean salinity threshold of $1.4 \mathrm{dS} \mathrm{m}^{-1}$ (Mass, 1993).

Nonetheless, according to the literature, the effects of salts on crops can vary depending on species, cultivar, phenological stage, and intensity and duration of the saline stress (Silva et al., 2012; Sousa et al., 2017). Thus, using salt-tolerant rootstocks can be an alternative to guarantee successful citrus production in Northeast Brazil.

Based on studies conducted with citrus in recent years (Fernandes et al., 2011; Hussain et al., 2012; Silva et al., 2012; Hussain et al., 2015; Sá et al., 2015; Brito et al., 2016; Barbosa et al., 2017; Sá et al., 2017) to obtain genetic materials with potential for tolerance to salinity, it becomes necessary to evaluate new crosses and hybrids, which can be done by studying parameters that can help interpret tolerance mechanisms.

In this context, this study aimed to evaluate the balance of salts in the substrate used for cultivation, under saline water application, of citrus rootstocks considered as tolerant and belonging to the progeny resulting from the cross between 'Sunki' mandarin and 'Swingle' citrumelo.

\section{Material ANd Methods}

The experiment was carried out from December 2015 to June 2016 in a protected environment (greenhouse) at the Center of Sciences and Agri-food Technology (CCTA) of the Federal University of Campina Grande (UFCG), Pombal-PB, Brazil (6 47' 20" S, 37 48' 01' W, altitude of $194 \mathrm{~m}$ ). The local climate is classified as BSh (hot and dry semi-arid), with mean annual rainfall of $750 \mathrm{~mm}$ and mean annual evapotranspiration of $2000 \mathrm{~mm}$.

Treatments were arranged in randomized blocks, in $2 \mathrm{x}$ 13 factorial scheme, corresponding to two levels of irrigation water salinity $\left(\mathrm{S} 1=0.3 \mathrm{dS} \mathrm{m}^{-1}\right.$ and $\left.\mathrm{S} 2=3 \mathrm{dS} \mathrm{m} \mathrm{m}^{-1}\right)$, which were used to irrigate 13 genotypes of rootstocks, 10 of which from the progeny of the cross between 'Sunki' mandarin and 'Swingle' citrumelo, namely TSKC x CTSW - 041, TSKC $\mathrm{x}$ CTSW - 042, TSKC x CTSW - 044, TSKC x CTSW - 045, TSKC x CTSW - 047, TSKC x CTSW - 048, TSKC x CTSW 049, TSKC x CTSW - 053, TSKC x CTSW - 055 and TSKC $\mathrm{x}$
CTSW - 057. 'Rangpur Santa Cruz' lime (C. limonia Osbeck) (LCRSTC), 'Sunki Tropical' mandarin ('Sunki Tropical') and the hybrid between Volkamer lemon (C. volkameriana V. Ten. \& Pasq.) (LVK) and 'Cravo' lemon (LCR) - 038 (LVK x LCR 038 ) were included as control, for being salt-tolerant according to Brito (2010) and Barbosa et al. (2017).

All factors combined led to 26 treatments (2 salinity levels $\mathrm{x} 13$ genotypes), repeated in 4 blocks, and each plot consisted of 1 plant, totaling 104 plots.

Seedlings were initially prepared in a protected environment at Embrapa Cassava and Fruits, considering all criteria for the initial production of rootstocks, such as the use of seeds from reputable companies, pest control and selection of nucellar plants.

At 75 days after sowing (DAS), the seedlings were transferred to 2000-mL black polyethylene bags and taken to the protected environment of the CCTA/UFCG, where the experiment was conducted. During growth period in the protected environment at Embrapa until the 90 DAS, the seedlings received public-supply water with low electrical conductivity $\left(\mathrm{ECw}=0.3 \mathrm{dS} \mathrm{m}^{-1}\right)$.

At 90 DAS, solutions with different salinity levels began to be applied and irrigation depths were daily determined based on the water balance, obtained by drainage lysimetry, adding a leaching fraction (LF) of 0.20 . In this process, the volume applied per bag (Va) was obtained by difference between the total volume applied in the previous night (Vta) and the volume drained $(\mathrm{Vd})$ in the next morning, applying the leaching fraction, as indicated in Eq. 1 for each treatment.

$$
\mathrm{Va}=\frac{\mathrm{Vta}-\mathrm{Vd}}{(1-\mathrm{LF})}(\mathrm{mL})
$$

Drained water was collected through a hose attached to the bottom of each bag and connected to a container, to measure the drained volume.

Nutritional management and all cautions with respect to weed control, and prevention and control of pests followed the recommendations for citrus seedling production proposed by Mattos Júnior et al. (2005).

Irrigation water of $3.0 \mathrm{dS} \mathrm{m}^{-1}$ was prepared in such a way to obtain an equivalent proportion of $7: 2: 1$, of $\mathrm{Na}: \mathrm{Ca}: \mathrm{Mg}$, respectively, using $\mathrm{NaCl}, \mathrm{CaCl}_{2} \cdot 2 \mathrm{H}_{2} \mathrm{O}$ and $\mathrm{MgCl}_{2} \cdot 6 \mathrm{H}_{2} \mathrm{O}$ salts. This ratio corresponds to the ions present in most water sources used for irrigation in small properties of Northeast Brazil (Audry \& Suassuna, 1995; Medeiros et al., 2003).

To prepare the solution with the desired electrical conductivity (ECw), the salts were added to the public-supply water, which had ECw of $0.3 \mathrm{dS} \mathrm{m}^{-1}$, corresponding to the first salinity level studied. After preparation, the solutions were stored in $60 \mathrm{~L}$ plastic containers, one for each ECw level, properly protected to avoid evaporation and contamination with materials that could compromise their quality. Every two days, electrical conductivity was measured in the solutions using a portable conductivity meter, with value automatically corrected to $25^{\circ} \mathrm{C}$, and its value was adjusted when necessary.

When the rootstocks had adequate diameter for grafting, about 0.5 to $0.7 \mathrm{~cm}$, which occurred at 210 DAS, plants were 
cut close to the soil and roots were collected. The material (shoots and roots) was packed and dried in a forced-air oven for $72 \mathrm{~h}$ to obtain the dry matter or total dry phytomass (TDP), measured with an analytical scale, and the data were expressed in grams per plant.

Then, the substrates filling the bags were collected, dried, sieved, stored and labeled in plastic bags for analyses at the Laboratory of Soil and Plant Nutrition of the CCTA/UFCG, where the ions $\mathrm{Ca}^{+2}, \mathrm{Mg}^{+2}, \mathrm{Na}^{+}$and $\mathrm{K}^{+}$, soluble $\mathrm{Cl}^{-}$and $\mathrm{ECw}$ were determined using the methodologies described in EMBRAPA (1997).

The obtained data were subjected to analysis of variance (ANOVA) by F test. In the cases of significance for the factor genotypes, means grouping test (Scott-Knott, $\mathrm{p}<0.05)$ was applied for each water salinity level. To verify the differences between salinity levels in each genotype, the F test was conclusive (Ferreira, 2011).

\section{Results AND Discussion}

Based on the balance of salts (Table 1), the use of saline water caused alterations in soil chemical characteristics, increasing the electrical conductivity of the saturation extract (ECse) and $\mathrm{Ca}^{+2}$ and $\mathrm{Na}^{+}$concentrations as the salinity levels increased, which caused the substrate to be classified as saline when irrigated with $3 \mathrm{dS} \mathrm{m}^{-1}$ water, resulting in ECse higher than $4 \mathrm{dS} \mathrm{m}^{-1}$ in all containers. Lowest ECse values occurred in the substrate cultivated with the genotypes TSKC $\mathrm{x}$ CTSW - 044, TSKC x CTSW - 045, TSKC x CTSW - 048, TSKC x CTSW - 049 and LCRSTC, irrigated with high-salinity water. The lowest ECse values also coincided with the lowest $\mathrm{Na}$ contents in the substrate cultivated with first two hybrids.

Such increase in the concentration of ions was due to the use of $\mathrm{Na}, \mathrm{Ca}$ and $\mathrm{Mg}$ salts to prepare the solution with the desired ionic concentration corresponding to the second salinity level $\left(3 \mathrm{dS} \mathrm{m}^{-1}\right)$. These results corroborate those obtained by Brito et al. (2015), studying salt balance in the substrate and growth of 'Tahiti' acid lime grafted with 'Sunki' mandarin hybrids, under saline stress. These authors observed that the increase of salt concentration in the irrigation water led to linear increase in the concentration of ions in the substrate.

Variation of ionic concentration in the substrates, due to the hybrids cultivated in it, can be interpreted as a quantitative difference in the nutritional demand between the genetic materials, i.e., the absorbed contents of nutrients usually vary between genotypes, as mentioned by Epstein \& Bloom (2006). In the literature on plant physiology, there are references to the selective permeability of the plasma membrane, adjusting the cell to the incorporation of ions according to plant needs, which vary depending on genetic constitution, development stage and conditions of soil and climate (Meer et al., 2008; Taiz et al., 2015). In addition, plants showed different growths, as can be observed in Table 2, based on the total dry phytomass.

For $\mathrm{Mg}^{+2}$ concentrations in the substrate solution (Table 3 ), there was no statistical difference between salinity levels for TSKC x CTSW-041, TSKC x CTSW - 042, TSKC x CTSW - 044, TSKC x CTSW - 045 and LVX x LCR - 038, although

Table 2. Test of means between citrus genotypes and between water salinity levels for total dry phytomass of citrus hybrids under water salinity

\begin{tabular}{|c|c|c|}
\hline \multirow{3}{*}{ Genotypes } & \multicolumn{2}{|c|}{ Total dry phytomass $(\mathrm{g})$} \\
\hline & \multicolumn{2}{|c|}{ Irrigation water salinity ( $\mathrm{dS} \mathrm{m}^{-1}$ ) } \\
\hline & 0.3 & 3 \\
\hline TSKC x CTSW - 041 & $4.805 \mathrm{Ba}$ & $4.925 \mathrm{Aa}$ \\
\hline TSKC x CTSW - 042 & $4.417 \mathrm{Ca}$ & $4.307 \mathrm{Ba}$ \\
\hline TSKC x CTSW - 044 & $4.601 \mathrm{Ba}$ & $4.480 \mathrm{Ba}$ \\
\hline TSKC x CTSW - 045 & $4.715 \mathrm{Ba}$ & $3.882 \mathrm{Bb}$ \\
\hline TSKC x CTSW - 047 & $5.594 \mathrm{Aa}$ & $4.964 \mathrm{Aa}$ \\
\hline TSKC $\times$ CTSW - 048 & $4.893 \mathrm{Ba}$ & $4.353 \mathrm{Ba}$ \\
\hline TSKC x CTSW - 049 & $4.244 \mathrm{Ca}$ & $4.778 \mathrm{Aa}$ \\
\hline TSKC x CTSW - 053 & $4.695 \mathrm{Ba}$ & $5.027 \mathrm{Aa}$ \\
\hline TSKC x CTSW - 055 & $6.094 \mathrm{Aa}$ & $5.253 \mathrm{Ab}$ \\
\hline TSKC x CTSW - 057 & $5.688 \mathrm{Aa}$ & $4.838 \mathrm{Ab}$ \\
\hline 'Rangpur Santa Cruz' lime & $4.209 \mathrm{Ca}$ & $4.199 \mathrm{Ba}$ \\
\hline LVK x LCR -038 & $5.639 \mathrm{Aa}$ & $4.467 \mathrm{Bb}$ \\
\hline 'Sunki Tropical' mandarin & $4.044 \mathrm{Ca}$ & $4.780 \mathrm{Aa}$ \\
\hline
\end{tabular}

Different uppercase letters indicate significant difference between hybrids by Scott-Knott test $(p<0.05)$ at a same salinity level, whereas different lowercase letters indicate significant difference between salinity levels by F test $(p<0.05)$ for a same genotype; TSKC - 'Sunki' mandarin [Citrus sunki (Hayata) hort. ex Tanaka]; CTSW - Swingle citrumelo [C. paradisi Macfad. x Poncirus trifoliata (L.) Raf.]; LVK - Volkamer lemon (C. volkameriana V. Ten. \& Pasq.); LCR - 'Rangpur' lime (C. limonia Osbeck); LCRSTC - 'Rangpur Santa Cruz' lime

Table 1. Test of means between genotypes and water salinity levels relative to electrical conductivity (ECse), and contents of calcium $\left(\mathrm{Ca}^{+}\right)$and sodium $\left(\mathrm{Na}^{+}\right)$in the substrate cultivated with citrus hybrids under water salinity

\begin{tabular}{|c|c|c|c|c|c|c|}
\hline \multirow{3}{*}{ Genotypes } & \multicolumn{2}{|c|}{ ECse $\left(d s ~ m^{-1}\right)$} & \multicolumn{2}{|c|}{$\mathrm{Ca}^{+2}\left(\mathrm{mmol}_{\mathrm{c}} \mathrm{dm}^{-3}\right)$} & \multicolumn{2}{|c|}{$\mathrm{Na}^{+}\left(\mathrm{mmol}_{\mathrm{c}} \mathrm{dm}^{-3}\right)$} \\
\hline & & & \multicolumn{2}{|c|}{ Irrigation water salinity $\left(\mathrm{dS} \mathrm{m}^{-1}\right)$} & & \\
\hline & 0.3 & 3 & 0.3 & 3 & 0.3 & 3 \\
\hline TSKC x CTSW - 041 & $2.236 \mathrm{Ab}$ & $6.655 \mathrm{Aa}$ & $2.442 \mathrm{Cb}$ & $3.539 \mathrm{Ca}$ & $11.957 \mathrm{Ab}$ & $42.223 \mathrm{Aa}$ \\
\hline TSKC $\times$ CTSW - 042 & $1.295 \mathrm{Ab}$ & $6.400 \mathrm{Aa}$ & $1.951 \mathrm{Cb}$ & $3.774 \mathrm{Ba}$ & $8.994 \mathrm{Ab}$ & $43.528 \mathrm{Aa}$ \\
\hline TSKC x CTSW - 044 & $1.328 \mathrm{Ab}$ & $4.793 \mathrm{Ba}$ & $2.062 \mathrm{Cb}$ & $3.143 \mathrm{Ca}$ & $7.493 \mathrm{Ab}$ & $37.939 \mathrm{Ba}$ \\
\hline TSKC $\times$ CTSW - 045 & $1.550 \mathrm{Ab}$ & $5.632 \mathrm{Ba}$ & $2.316 \mathrm{Cb}$ & $3.288 \mathrm{Ca}$ & $9.277 \mathrm{Ab}$ & $37.644 \mathrm{Ba}$ \\
\hline TSKC $\times$ CTSW - 047 & $1.894 \mathrm{Ab}$ & $6.992 \mathrm{Aa}$ & $2.292 \mathrm{Cb}$ & $3.990 \mathrm{Ca}$ & $11.449 \mathrm{Ab}$ & $45.548 \mathrm{Aa}$ \\
\hline TSKC $\times$ CTSW - 048 & $1.141 \mathrm{Ab}$ & $5.166 \mathrm{Ba}$ & $2.127 \mathrm{Cb}$ & $3.241 \mathrm{Ca}$ & $8.971 \mathrm{Ab}$ & $40.835 \mathrm{Aa}$ \\
\hline TSKC $\times$ CTSW - 049 & $1.535 \mathrm{Ab}$ & $4.740 \mathrm{Ba}$ & $2.046 \mathrm{Cb}$ & $3.466 \mathrm{Ca}$ & $8.814 \mathrm{Ab}$ & $40.947 \mathrm{Aa}$ \\
\hline TSKC $\times$ CTSW - 053 & $0.985 \mathrm{Ab}$ & $6.655 \mathrm{Aa}$ & $1.818 \mathrm{Cb}$ & $3.259 \mathrm{Ca}$ & $8.890 \mathrm{Ab}$ & $43.402 \mathrm{Aa}$ \\
\hline TSKC x CTSW - 055 & $1.429 \mathrm{Ab}$ & $7.432 \mathrm{Aa}$ & $2.177 \mathrm{Cb}$ & $4.014 \mathrm{Ba}$ & $9.816 \mathrm{Ab}$ & $46.685 \mathrm{Aa}$ \\
\hline TSKC x CTSW - 057 & $2.377 \mathrm{Ab}$ & $6.872 \mathrm{Aa}$ & $2.959 \mathrm{Bb}$ & $3.954 \mathrm{Ba}$ & $11.592 \mathrm{Ab}$ & $45.271 \mathrm{Aa}$ \\
\hline 'Rangpur Santa Cruz' lime & $1.355 \mathrm{Ab}$ & $5.620 \mathrm{Ba}$ & $2.059 \mathrm{Ca}$ & $3.094 \mathrm{Ca}$ & $10.405 \mathrm{Ab}$ & $40.523 \mathrm{Aa}$ \\
\hline LVK x LCR - 038 & $2.923 \mathrm{Ab}$ & $6.065 \mathrm{Aa}$ & $3.593 \mathrm{Ab}$ & $3.437 \mathrm{Ca}$ & $13.405 \mathrm{Ab}$ & $43.680 \mathrm{Aa}$ \\
\hline 'Sunki Tropical' mandarin & $1.089 \mathrm{Ab}$ & $7.296 \mathrm{Aa}$ & $1.823 \mathrm{Cb}$ & $4.712 \mathrm{Aa}$ & $8.141 \mathrm{Ab}$ & $43.248 \mathrm{Aa}$ \\
\hline
\end{tabular}

Different uppercase letters indicate significant difference between hybrids by Scott-Knott test $(\mathrm{p}<0.05)$ at a same salinity level, whereas different lowercase letters indicate significant difference between salinity levels by F test $(\mathrm{p}<0.05)$ for a same genotype; TSKC - 'Sunki' mandarin [Citrus sunki (Hayata) hort. ex Tanaka]; CTSW - 'Swingle' citrumelo [C. paradisi Macfad. x Poncirus trifoliata (L.) Raf.]; LVK - Volkamer lemon (C. volkameriana V. Ten. \& Pasq.); LCR - 'Rangpur Santa Cruz' lime (C. limonia Osbeck); LCRSTC - 'Rangpur Santa Cruz' lime 
$\mathrm{MgCl}_{2} 6 \mathrm{H}_{2} \mathrm{O}$ was added to the water, in the treatment with highest salinity ( $\left.3 \mathrm{dS} \mathrm{m}^{-1}\right)$, which can be related to greater fixation to soil colloids and/or absorption by the genotypes, which had higher demand for the nutrient.

Regarding K contents in the extract, the increase in salinity raised the concentration in the substrate cultivated with the hybrids TSKC $\mathrm{x}$ CTSW- 042, TSKC $\mathrm{x}$ CTSW - 047, TSKC $\mathrm{x}$ CTSW - 048, TSKC x CTSW - 053, TSKC x CTSW- 055, TSKC x CTSW - 057, as well as 'Sunki Tropical' mandarin, which can be attributed to the reserves (stock) of this nutrient adsorbed to the colloids, besides the fertilizations.

Additionally, greater presence of $\mathrm{Ca}^{+2}, \mathrm{Mg}^{+2}$ and $\mathrm{Na}^{+2}$ ions, applied through irrigation water, may have consequently increased the competition for the adsorption sites; $\mathrm{Na}^{+2}, \mathrm{Ca}^{+2}$ and $\mathrm{Mg}^{+2}$ are attracted and bound to the colloids, releasing $\mathrm{K}^{+}$ to the solution.

Garcia-Sánchez et al. (2006), cultivating 7-year-old plants of 'Clemenules' mandarin (C. Clementina hort. ex. Tanaka) grafted onto two rootstocks ['Cleopatra' mandarin (C. reshni hort. ex Tanaka) and 'Carrizo' citrange (C. sinensis x $P$. trifoliata)], irrigated with water containing $\mathrm{NaCl}$ at the concentrations of 3, 15 and $30 \mathrm{mM}$, for three years, observed increase of toxic ions $\left(\mathrm{Cl}^{-}\right.$and $\left.\mathrm{Na}^{+}\right)$and reduction of $\mathrm{N}, \mathrm{P}$ and $\mathrm{K}$ contents in the leaves. Reduction of $\mathrm{K}^{+}$concentration in the plant due to increasing salinity is among the most studied effects, and the selective $\mathrm{K}^{+}$adsorption capacity associated with $\mathrm{Na}^{+2}$ exclusion is known as the tolerance mechanism of some plants to the saline stress (Willadino \& Camara, 2010). In addition, elevated concentrations of $\mathrm{Ca}^{+2}$ and $\mathrm{Mg}^{+2}$ reduce $\mathrm{K}$ absorption by competitive inhibition, although low $\mathrm{Ca}^{+2}$ concentrations have synergetic effect on the nutrition of a few species (Faquin, 2005).

Chlorine is considered as an essential element to plants, but at the concentration of a micronutrient; at high concentrations, it is toxic. According to the data in Table 3, there was $\mathrm{Cl}$ accumulation in the substrate under irrigation with $\mathrm{EC}=3.0 \mathrm{dS} \mathrm{m}^{-1}$. Nonetheless, even under such conditions and although chlorine is the most harmful element to citrus species, when at high contents (Hussain et al., 2012; Syvertsen \& Garcia-Sanchez, 2014; Brito et al., 2015), plants maintained their growth.
As already mentioned previously, besides reducing ECse and $\mathrm{Na}^{+}$content in the substrate cultivated with some genotypes, more evident in TSKC x CTSW - 044 and TSKC $\mathrm{x}$ CTSW - 045, in these hybrids and also in TSKC x CTSW 048, chlorine contents were lower when plants were irrigated with high-salinity water.

To survive under these conditions, plants may have used mechanisms of tolerance to the stressful condition because, according to Gheyi et al. (2016), $\mathrm{Cl}^{-}$-sensitive plants may exhibit symptoms of toxicity, which consist of burn on tip of the leaves, reaching the edges in advanced stages; in general, premature leaf abscission occurs, and these symptoms appear when chloride concentration reaches 0.3 to $1.0 \%$, based on leaf dry matter. Also according to these authors, the maximum chloride level (in $\mathrm{mmol}_{\mathrm{c}} \mathrm{dm}^{-3}$ ) in the saturation extract for Cleopatra mandarin, bitter orange and sweet orange cannot exceed 25,

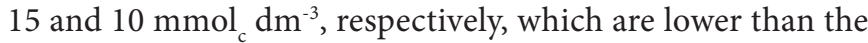
values observed in the present study, as the contents of $\mathrm{Na}^{+}$ions.

In the same context, Ayers \& Westcot (1999) cite $10 \mathrm{mmol}_{\mathrm{c}} \mathrm{dm}^{-3}$ as maximum limit allowed of chloride for citrumelo, which would make the salinity observed in the present study even more harmful, considering the values found in the substrate cultivated with the 'Sunki' x 'Swingle' hybrids (TSKC x CTSW), denoting the tolerance capacity of these genotypes.

Complementing this discussion, phytomass data of the genotypes are presented in Table 2, showing differences between rootstocks at each level of water salinity. Even with the use of water containing low salt concentration $\left(0.3 \mathrm{dS} \mathrm{m}^{-1}\right)$, it is noticeable the difference of vigor between the genotypes, particularly TSKC x CTSW - 047, LVK x LCR - 038, TSKC $\mathrm{x}$ CTSW - 055 and TSKC x CTSW - 057. These latter two were affected by salinity when plants were irrigated with saline water $\left(3 \mathrm{dS} \mathrm{m}^{-1}\right)$, but even in this condition they remained in the group of higher phytomass.

Except for the two genotypes cited (TSKC x CTSW - 055 and TSKC $x$ CTSW - 057), the rootstocks TSKC x CTSW - 045 and LVK $x$ LCR - 038 were affected also by the highest salinity, because they remained in an inferior group of tolerance to saline stress.

Table 3. Test of means for potassium $\left(\mathrm{K}^{+}\right)$, magnesium $\left(\mathrm{Mg}^{+2}\right)$ and chloride $\left(\mathrm{Cl}^{-}\right)$in the substrate cultivated with citrus hybrids subjected to water salinity

\begin{tabular}{|c|c|c|c|c|c|c|}
\hline \multirow{3}{*}{ Genotypes } & \multicolumn{2}{|c|}{$\mathrm{K}^{+}\left(\mathrm{mmol}_{\mathrm{c}} \mathrm{dm}^{-3}\right)$} & \multicolumn{2}{|c|}{$\mathrm{Mg}^{+2}\left(\mathrm{mmol}_{\mathrm{c}} \mathrm{dm}^{-3}\right)$} & \multicolumn{2}{|c|}{$\mathrm{Cl}^{-}\left(\mathrm{mmol}_{\mathrm{c}} \mathrm{dm}^{-3}\right)$} \\
\hline & & & \multicolumn{2}{|c|}{ Irrigation water salinity $\left(\mathrm{dS}^{-1}\right)$} & & \\
\hline & 0.3 & 3 & 0.3 & 3 & 0.3 & 3 \\
\hline TSKC $\times$ CTSW - 041 & $6.084 \mathrm{Aa}$ & $3.082 \mathrm{Ab}$ & $3.121 \mathrm{Aa}$ & $3.393 \mathrm{Aa}$ & $19.166 \mathrm{Ab}$ & $81.875 \mathrm{Ba}$ \\
\hline TSKC $\times$ CTSW - 042 & $1.840 \mathrm{Bb}$ & $4.701 \mathrm{Aa}$ & $2.629 \mathrm{Aa}$ & $2.990 \mathrm{Ba}$ & $12.500 \mathrm{Ab}$ & $82.500 \mathrm{Ba}$ \\
\hline TSKC x CTSW - 044 & $1.529 \mathrm{Ba}$ & $2.758 \mathrm{Aa}$ & $2.499 \mathrm{Ba}$ & $2.529 \mathrm{Ba}$ & $11.875 \mathrm{Ab}$ & $70.833 \mathrm{Ca}$ \\
\hline TSKC x CTSW - 045 & $2.136 \mathrm{Ba}$ & $3.066 \mathrm{Aa}$ & $2.317 \mathrm{Ba}$ & $2.548 \mathrm{Ba}$ & $14.375 \mathrm{Ab}$ & $64.375 \mathrm{Ca}$ \\
\hline TSKC x CTSW - 047 & $1.620 \mathrm{Bb}$ & $3.744 \mathrm{Aa}$ & $3.062 \mathrm{Ab}$ & $3.744 \mathrm{Aa}$ & $14.375 \mathrm{Ab}$ & $79.375 \mathrm{Ba}$ \\
\hline TSKC x CTSW - 048 & $0.808 \mathrm{Bb}$ & $3.231 \mathrm{Aa}$ & $2.115 \mathrm{Bb}$ & $3.009 \mathrm{Ba}$ & $10.416 \mathrm{Ab}$ & $70.833 \mathrm{Ca}$ \\
\hline TSKC x CTSW - 049 & $1.367 \mathrm{Ba}$ & $2.529 \mathrm{Aa}$ & $2.245 \mathrm{Bb}$ & $3.152 \mathrm{Ba}$ & $11.666 \mathrm{Ab}$ & $73.833 \mathrm{Ba}$ \\
\hline TSKC x CTSW - 053 & $1.168 \mathrm{Bb}$ & $3.136 \mathrm{Aa}$ & $2.167 \mathrm{Bb}$ & $3.472 \mathrm{Aa}$ & $13.125 \mathrm{Ab}$ & $83.125 \mathrm{Ba}$ \\
\hline TSKC x CTSW - 055 & $1.061 \mathrm{Bb}$ & $3.733 \mathrm{Aa}$ & $1.690 \mathrm{Bb}$ & $3.472 \mathrm{Aa}$ & $18.750 \mathrm{Ab}$ & $103.75 \mathrm{Aa}$ \\
\hline TSKC $\times$ CTSW - 057 & $2.098 \mathrm{Bb}$ & $4.846 \mathrm{Aa}$ & $2.856 \mathrm{Ab}$ & $3.533 \mathrm{Aa}$ & $15.000 \mathrm{Ab}$ & $85.625 \mathrm{Ba}$ \\
\hline 'Rangpur Santa Cruz' lime & $1.679 \mathrm{Ba}$ & $2.749 \mathrm{Aa}$ & $2.046 \mathrm{Bb}$ & $2.935 \mathrm{Ba}$ & $15.625 \mathrm{Ab}$ & $76.875 \mathrm{Ba}$ \\
\hline LVK $\times$ LCR - 038 & $2.156 \mathrm{Ba}$ & $2.803 \mathrm{Aa}$ & $3.234 \mathrm{Aa}$ & $3.007 \mathrm{Ba}$ & $15.000 \mathrm{Ab}$ & $78.125 \mathrm{Ba}$ \\
\hline Sunki 'Tropical' mandarin & $1.448 \mathrm{Bb}$ & $4.077 \mathrm{Aa}$ & $2.401 \mathrm{Bb}$ & $4.016 \mathrm{Aa}$ & $12.812 \mathrm{Ab}$ & $81.250 \mathrm{Ba}$ \\
\hline
\end{tabular}

Different uppercase letters indicate significant difference between hybrids by Scott-Knott test $(p<0.05)$ at a same salinity level, whereas different lowercase letters indicate significant difference between salinity levels by F test $(\mathrm{p}<0.05)$ for a same genotype; TSKC - 'Sunki' mandarin [Citrus sunki (Hayata) hort. ex Tanaka]; CTSW - 'Swingle' citrumelo [C. paradisi Macfad. $x$ Poncirus trifoliata (L.) Raf.]; LVK - 'Volkamer' lemon (C. volkameriana V. Ten. \& Pasq.); LCR - 'Rangpur' lime (C. limonia Osbeck); LCRSTC - 'Rangpur Santa Cruz' lime 
Among the genetic materials, TSKC x CTSW - 055 stands out in the group of genotypes with higher dry matter accumulation in the treatments of both lower and higher salinity, with EC of $7.43 \mathrm{dS} \mathrm{m}^{-1}$ in the saturation extract of the substrate where it was cultivated (Table 1) and chloride concentration of $103.75 \mathrm{mmol} \mathrm{dm}^{-3}$ (Table 3). The EC value is much higher than that of salinity threshold for citrus plants, and chloride concentration exceeds the respective level of toxicity reported in the literature (Ayers \& Westcot, 1999).

The highest ECw level did not affect the phytomass of most rootstocks, an evidence of their potential to be used under saline conditions, particularly TSKC x CTSW - 041, TSKC $\mathrm{x}$ CTSW - 047, TSKC x CTSW - 049, TSKC x CTSW - 053, as well as 'Sunki Tropical' mandarin, a difference attributed to the hybrid potential of each material (Fernandes et al., 2011; Barbosa et al., 2017).

\section{Conclusions}

1. Increasing water salinity modifies the absorption nutrient by the genotypes, which have different nutritional demands.

2. Salinization of the substrate irrigated with $3 \mathrm{dS} \mathrm{m}^{-1}$ water is lower when cultivated with the hybrids TSKC x CTSW - 044, TSKC x CTSW - 045, TSKC x CTSW - 048, TSKC x CTSW 049, and 'Rangpur Santa Cruz' lime.

3. Higher concentration of salts in the water increases $\mathrm{K}^{+}$ concentration in the substrate cultivated with the hybrids TSKC x CTSW - 042, TSKC x CTSW - 047, TSKC x CTSW 048, TSKC x CTSW - 053, TSKC x CTSW - 055 and TSKC $\mathrm{x}$ CTSW - 057, indicating lower absorption of $\mathrm{K}^{+}$.

\section{ACKNOWLEDgments}

To the National Council for Scientific and Technological Development $(\mathrm{CNPq})$, for providing financial resources through the Universal call $014 / 2014$ and research grants; to Embrapa Cassava and Fruits, for the partnership in the study.

\section{Literature Cited}

Araújo Neto, J. R. de; Andrade, E. M. de; Meireles, A. C. M.; Guerreiro, M. J. S.; Palácio, H. A. de Q. Proposta de índice da salinidade das águas superficiais de reservatórios do Ceará, Brasil. Revista Agro@mbiente On-line, v.8, p.184-193, 2014.

Audry, P.; Suassuna, J. A. A qualidade da água na irrigação do trópico semiárido: Um estudo de caso. In: Seminário Franco-Brasileiro de Pequena Irrigação, 1995, Recife. Anais... Recife: CNPq/SUDENE, 1995. p.147-153.

Ayers, R. S.; Westcot, D. W. A qualidade da água na agricultura. Campina Grande: UFPB, 1999. 184p.

Barbosa, R. C. A.; Brito, M. E. B.; Sá, F. V. da S.; Soares Filho, W. dos S.; Fernandes, P. D.; Silva, L. de A. Gas exchange of citrus rootstocks in response to intensity and duration of saline stress. Semina: Ciências Agrárias, v.38, p.725-738, 2017. https://doi. org/10.5433/1679-0359.2017v38n2p725

Brito, M. E. B. Tolerância de genótipos de citros ao estresse salino. Campina Grande: Universidade Federal de Campina Grande, 2010. 155p. Tese Doutorado
Brito, M. E. B.; Sá, F. V. da S.; Soares Filho, W. dos S.; Silva, L. A.; Fernandes, P. D. Trocas gasosas e fluorescência de variedades de porta-enxerto cítricos sob estresse salino. Revista Brasileira de Fruticultura, v.38, p.1-8, 2016.

Brito, M. E. B.; Silva, E. C. da B.; Fernandes, P. D.; Soares Filho, W. dos S.; Coelho Filho, M. A.; Sá, F. V. da S.; Melo, A. S. de; Barbosa, R. C. A. Salt balance in substrate and growth of 'Tahiti' acid lime grafted onto Sunki mandarin hybrids under salinity stress. Australian Journal of Crop Science, v.9, p.954-961, 2015.

Dalastra, C.; Hernandez, F. B. T.; Barboza, G. C.; Sonego, C. R. Qualidade da água do córrego do cedro para fins de irrigação na produção de alimentos consumidos in-natura. Revista de Agricultura Neotropical, v.1, p.52-63, 2014.

EMBRAPA - Empresa Brasileira de Pesquisa Agropecuária. Manual de métodos de análise de solo. Rio de Janeiro: Embrapa Solos, 1997. 212p.

Epstein, E.; Bloom, A. J. Nutrição mineral de plantas: Princípios e perspectivas. Londrina: Editora Planta, 2006. 403p.

Faquin, V. Nutrição mineral de plantas. Lavras: UFLA/FAEPE, 2005. $186 \mathrm{p}$.

Fernandes, P. D.; Brito, M. E. B.; Gheyi, H. R.; Soares Filho, W. dos S.; Melo, A. S. de; Carneiro, P. T. Crescimento de híbridos e variedades porta-enxerto de citros sob salinidade. Acta Scientiarum. Agronomy, v.33, p.259-267, 2011.

Ferreira, D. F. Sisvar: A computer statistical analyses system. Ciência e Agrotecnologia, v.35, p.1039-1042, 2011. https://doi.org/10.1590/ S1413-70542011000600001

García-Sánchez, F.; Perez-Perez, J. G.; Botia, P.; Martínez, V. The response of young mandarin trees grown under saline conditions depends on the rootstock. European Journal of Agronomy, v.24, p.129-139, 2006. https://doi.org/10.1016/j.eja.2005.04.007

Gheyi, H. R.; Dias, N. S. da.; Lacerda, C. F. de; Gomes Filho, E. Manejo da salinidade na agricultura: Estudos básicos e aplicados. 2.ed. Fortaleza: INCT Sal, 2016. 506p.

Hussain, S.; Luro, F.; Costantino, G.; Ollitrault, P.; Morillon, R. Physiological analysis of salt stress behaviour of citrus species and genera: Low chloride accumulation as an indicator of salt tolerance. South African Journal of Botany, v.81, p.103-112, 2012. https://doi.org/10.1016/j.sajb.2012.06.004

Hussain, S.; Morillon, R.; Anjum, M. A.; Ollitrault, P.; Costantino, G.; Luro, F. Genetic diversity revealed by physiological behavior of citrus genotypes subjected to salt stress. Acta Physiologiae Plantarum, v.37, p.1740-1750, 2015. https://doi.org/10.1007/ s11738-014-1740-4

Mass, E. V. Salinity and citriculture. Tree Physiology, v.12, p.195-216, 1993. https://doi.org/10.1093/treephys/12.2.195

Mattos Júnior, D.; Negri, J. D. de; Pio, R. S.; Pompeu Júnior, J. Citros. Campinas: IAC/FUNDAG, 2005. 929p.

Medeiros, J. F. de; Lisboa, R. de A.; Oliveira, M. de; Silva Júnior, M. J. da; Alves, L. P. Caracterização das águas subterrâneas usadas para irrigação na área produtora de melão da Chapada do Apodi. Revista Brasileira de Engenharia Agrícola e Ambiental, v.7, p.469472, 2003. https://doi.org/10.1590/S1415-43662003000300010

Meer, G. van; Voelker, D. R.; Feigenson, G. W. Membrane lipids: Where they are and how they behave. Nature Reviews Molecular Cell Biology, v.9, p.112-124, 2008. https://doi.org/10.1038/nrm2330 
Sá, F. V. da S.; Brito, M. E. B.; Figueiredo, L. C. de; Melo, A. S. de; Silva, L. de A.; Moreira, R. C. L. Biochemical components and dry matter of lemon and mandarin hybrids under salt stress. Revista Brasileira de Engenharia Agrícola e Ambiental, v.21, p.249-253, 2017. https://doi.org/10.1590/1807-1929/agriambi. v21n4p249-253

Sá, F. V. da S.; Brito, M. E. B.; Silva, L. A. de; Moreira, R. C. L.; Fernandes, P. D.; Figueiredo, L. C. de. Fisiologia da percepção do estresse salino em híbridos de tangerineira "Sunki Comum" sob solução hidropônica salinizada. Comunicata Scientiae, v.6, p.463-470, 2015. https://doi.org/10.14295/cs.v6i4.1121

Silva, F. V. da; Soares, F. A. L.; Gheyi, H. R.; Travassos, K. D.; Suassuna, J. F.; Cardoso, J. A. F. Produção de citros irrigados com água moderadamente salina. Irriga, v.especial, p.396-407, 2012.
Sousa, G. G. de; Viana, T. V. de A.; Rebouças Neto, M. de O.; Silva, G. L. da.; Azevedo, B. M. de; Costa, F. R. B. Características agronômicas do girassol irrigado com águas salinas em substratos com fertilizantes orgânicos. Revista Agrogeoambiental, v.9, p.6575, 2017. https://doi.org/10.18406/2316-1817v9n12017920

Syvertsen, J. P.; García-Sáchez, F. Multiple abiotic stresses occurring with salinity stress in citrus. Environment and Experimental Botany, v.103, p.128-137, 2014. https://doi.org/10.1016/j. envexpbot.2013.09.015

Taiz, L.; Zeiger, E.; Moller, I. M.; Murphy, A. Plant physiology and development. 6.ed. Sunderland: Sinauer Associates, 2015. 885p.

Willadino, L.; Camara, R. T. Tolerância das plantas à salinidade: Aspectos fisiológicos e bioquímicos. Enciclopédia Biosfera, v.6, p.2-21, 2010. 